\title{
Climate changes not carbon, and evaporation
}

\section{Introduction}

Millions of years formed a water circuit between the atmosphere and soil, built a dynamic equilibrium. A certain amount of evaporation from the earth created such a mechanism of atmospheric phenomena, which sent water to the specified places of the planet by clouds. So various arid zones were formed - steppes, deserts, tropics, forests.

Civilization turned water into a working reagent. Water has become the main active body in many industrial and municipal processes a carrier of heat, energy, means of cooling, quenching, washing, washing, wet cleaning of everything that surrounds us. All direct evaporation from these processes and evaporation after the sewage of used water is unnatural, let's call them artificial. The natural path of water is its movement and transformation in food chains in the soil and on the soil through biota - microbes, worms, plants and animals. In each of them, water undergoes numerous transformations, and in the form of exhalation, transpiration, juices and other secretions, it again turns into a vaporous state. All these organic evaporations combine in the atmosphere, and create their own, unique mechanism for the formation of clouds, which was perfected before the appearance of man. We have destroyed more than $60 \%$ of this idyll - the soil and the living creatures living on it with plants, creating arable land, reservoirs, landfills, asphalt, concrete.

The volume and speed of artificial vapor increases with increasing acceleration in accordance with the development of technology. Approaching their limits, they began to exceed organic values in terms of quality, volume and turnover rate. The mechanism of the formation of atmospheric phenomena broke. Megatons of newquality water began to be shed by precipitation not in places specified by nature, not in prescribed volumes, not at a specified time, but according to other laws and rules unknown to nature. Quantity goes into quality. That is why in some places of precipitation excess with floods, in others - drought and fires. Arid zones are crumbling, species of plants and animals disappear, the level of the oceans rises - water does not reach the polar and mountain glaciers in clouds, falling along the way. Glaciers are not replenished - the everlasting process of transformation, storage and renewal of water is being destroyed. Glaciers are disappearing, the planet is changing.

All the efforts of mankind, directed by the Paris Agreements, lead to a catastrophe, because it is not carbon that affects the atmosphere, but evaporation. Spending funds on microscopic effects - reducing $\mathrm{CO}_{2}$ emissions, we do not pay attention to the main, source of natural disasters, the climate destroyer.

According to UN experts, " "the increase in $\mathrm{CO}_{2}$ emissions ranged from 0.5 to $5 \%$ per year. As a result, over the past hundred years, 400billion tons of carbon dioxide has just entered the atmosphere due to the burning of fuel. " Or 4 billion tons per year.

According to, ${ }^{2}$ annually mankind extracts up to 20thousand cubic kilometers of groundwater for its needs. Plus, according to, ${ }^{3}$ people irrevocably take away about 2 thousand cubic kilometers of fresh water from rivers and lakes annually. Almost all of this water is extracted from natural circulation, is used in agriculture, industry, utilities, and
Volume 7 Issue 6 - 2018

\author{
Oleg Halidullin \\ Kazakh National University,Alb-Farabi, Russia
}

Correspondence: Oleg Halidullin, Kazakh National University, Junior researcher Alb-Farabi, Russia, Email 71I53I5@mail.ru

Received: November 20, 2018 | Published: November 27, 2018

through sewage and evaporation goes into the atmosphere without organic changes. A 22,000cu kilometer is 22 trillion cubic meters, meters or tons of water. In the composition of the fumes, the emission of 4 billion tons of $\mathrm{CO}_{2}$ is just $0.018 \%$ - an imperceptible drop. Can this drop, which is 5,500times less than artificial evaporation alone, influence something? The ratio can be safely doubled by adding organic evaporation, with the remaining half of the land in its natural state.

One of the elements of the Paris Agreement is to reduce the burning of all types of fuel and the transition to alternative energy sources. Among these sources are hydropower plants. For example, in China, according to 4500 billion yuan will go to hydropower. Hydropower is hydroelectric. The most powerful Three Gorges HPP in the world is being completed, followed by several other projects. Thousands of hectares of fertile land are flooded by reservoirs. New hydropower plants are planned in many other countries. For example, Rogun in Tajikistan. This is a new artificial vapor. Reducing $\mathrm{CO}_{2}$ emissions by thousandths of a percent, we increase artificial emissions by tens of percent and reduce organic evaporation.

We plowed up even larger areas, $9 \%$ of all land, by deep plowing. ${ }^{5}$ Water precipitation falling on arable land does not find underground natural inhabitants and immediately goes back into the atmosphere without any changes. We fill up large territories with garbage and dumps of the mining industry. Under multimeter layers of such dumps, underground life is dying out, organic evaporation disappears.

The area of world forest has decreased to $30 \%$. Trees evaporate purely organic fumes. The hectare of the forest near Moscow evaporates over the summer through the leaves of about 44tons of water. This means that from the soil plants absorb moisture much more. In total, the plants of the planet for a year absorb 650trillion waters, and champions - tropical forests. It is estimated that in a million years the plants of the planet would have been able to dry all the seas and oceans. ${ }^{6}$ In total in the world more than 3 billion hectares of land are subject to desertification ${ }^{7}$ this is 30 million $\mathrm{km}^{2}$ or $20 \%$ of the total land area -149 million $\mathrm{km}^{2}$. According to other sources $63 \%$. In any case, they have become commensurate with the total territory and continue to grow. If we want to save the lives of our descendants and life on the planet in general, we must adopt a new concept of returning its natural functions to water. The scientific proof of this hypothesis is fairly simple and lies on the surface. Proponents and specialists who organize research with solid forces are needed. 


\section{Acknowledgments}

None.

\section{Conflicts of interest}

Author does not have any conflicts of interests

\section{References}

1. http://www.refsru.com/referat-17732 -3.html.

2. http://jkg-portal.com.ua/en/publication/one/globalna-posuha-aboproblemi-vodospozhivannja-32688
3. http://www.kursach.com/geografiya -ekonomicheskaya-geografiya / 816-referat-gidrosfera-v-sostave-biosferi / view-details.html.

4. https://www.dw.com/en/china-to-invest-360-bln-in-renewable -powerin-2016-2020 / a-37031957

5. https://ru.wikipedia.org/wiki/Powerland.

6. http://sitekid.ru/biologiya/interesnye_fakty_o_rasteniyah/skolko_ vody_potreblyayut_derevya.html.

7. http//referatwork.ru/lectionbase/ekologiya/view/80689 opustynivanie_i_otchuzhdenie_zemel. 